\title{
FACTORS RELATED TO BODY IMAGE AND IT CORRELATION WITH NUTRITIONAL STATUS AMONG FEMALE ADOLESCENTS: A LITERATURE REVIEW
}

\author{
Lusiana Pradana Hariyanti ${ }^{1}$, Nila Reswari Haryana ${ }^{2}$ \\ ${ }^{1}$ Undegraduate Study Program of Nutrition Science, Faculty of Public Health, Universitas Airlangga \\ ${ }^{2}$ Study Program of Nutrition, Faculty of Engineering, Universitas Negeri Medan \\ *E-mail: lusianapradanahariyanti@gmail.com
}

\begin{abstract}
Adolescence is the transition period from children to adults. Adolescents, especially girls, are vulnerable to nutritional problem, one of the factors is due to the perception of body image. Body image can affect nutritional status if an individual has a negative body image, in which the perception that someone consciously or unconsciously cannot accept her body shape. It affects the behavior of adolescent girls related to nutrition to achieve their body goal in various ways that increase risk of becoming nutritional problems (under or over nutrition). The aims of this study is find out factors related to body image and it correlation with nutritional status in female adolescent using a literature review approach. This literature review research takes various sources of articles which published in the last 10 years (2010-2020) related to the research topics. Article were searched through the PubMed - Medline and Google Scholar databases using. Keywords "body image", "nutritional status", and "adolescent girl". Eighteen articles according to the topic and criteria were selected for review. Based on the results of the study, it was found that body image is related to the nutritional status of adolescent girls. This is related to the lack of nutritional knowledge of adolescent girls, which affects to an unhealthy and unbalanced diet. Besides, there is also a correlation of physical activity that is not balanced with food intake and the role of the environment such as family and friends which also affects knowledge, food intake, and body image of adolescent girls.
\end{abstract}

Keywords: Body Image, Literature Review, Adolescent Girls, Nutritional Status

\section{INTRODUCTION}

Adolescence is a period when an individual has significant and important changes which are distincted by physical, cognitive, psychological, hormonal, and social in developing individual towards adulthood (Vieira et al., 2015). The World Health Organization (WHO) classify that adolescents as individual aged 10-19 years. In this period, puberty occurs then reaches sexual maturity (Permatasari et al., 2017).

Puberty that happens in adolescents, especially for adolescent girls, create significant physical and psychological changes. Physical changes involve the gain of weight and height, body proportions on the shoulders, arms, waist, and sexual changes including primary and secondary changes. (Pasaribu et al., 2015). Whereas the psychological changes that occur involve an identity crisis, an unstable spirit, emotional changes, tend to be childish, often sad/moody, and take more attention to the body shape. Physical changes in adolescents which followed by psychological changes cause adolescents to be lack satisfaction with their body shape. Thus, during puberty, adolescent girls prone to have nutritional problems due to lifestyle changes to reach their body goal.

Based on the 2018 Indonesia basic health research data, 22 out of 100 adolescents aged 1618 years are short, even 5 out of 100 adolescents are very short. Based on nutritional status (BMI / age), $14.5 \%$ are having over-nutrition status, while $8.1 \%$ had undernutrition status. (Kemenkes RI, 2019). Adolescent girls take a role in improving nutrition that focuses on the First 1000 Days of Life, although it is not directly stated. The nutritional status of adolescent girls has a crucial impact on health and safety during pregnancy and childbirth in the future. (Bapenas RI, 2012).

One of the puberty changes creates a change in the perception of body shape which is often referred to as body image. Body image is the perception, thoughts, and beliefs of an individual consciously about the shape of the body (Brown, 2011). There are two categories of body image, 
namely positive and negative. A positive body image is when an individual is satisfied and acceptable with changes in her body shape (Jannah et al, 2019). Meanwhile, negative body image is when an individual can not accept her body shape (Bimantara et al, 2019).

Factors that lead to nutritional status changes can be caused by an individual having a negative body image such as irregular meal patterns and lack of intake of both macro and micronutrients, poor physical activity, exposure to misinformation from social media, lack of nutritional knowledge, and inappropriate peer influence (Normate et al, 2017).

The meal pattern changes which happens because most adolescents, especially adolescent girls want to have an ideal body. According to them, the ideal body is classified as a thin and slender body, so efforts are needed to reduce weight (Mawaddah et al, 2019). Most of the methods which are done by the adolescent girl are not quite right, a strict diet without take attention to the nutritional needs (Widianti, 2012).

When negative body image continues to happen for a long time, it will increase the risk of malnutrition and eating disorders such as anorexia nervosa and bulimia nervosa, so it will create an impact on the nutritional and health status of adolescent girls. (Widianti, 2012). Thus, the researcher aims to examine the correlation of body image and nutritional status in adolescent girls through a literature review approach from various existing studies and articles.

\section{METHODS}

This literature review is accomplished by searching for several articles that include observational studies, such as cohorts, casecontrol, and cross-sectional. The main article type chosen was observational research on body image with nutritional status in adolescents in the last 10 years (2010-2020). Articles were searched using electronic databases such Google Scholar, and PubMed / Medline.

The articles used were traced with the three keywords such as body image, adolescent, and nutritional status in accessible national and international journals. The inclusion criteria used

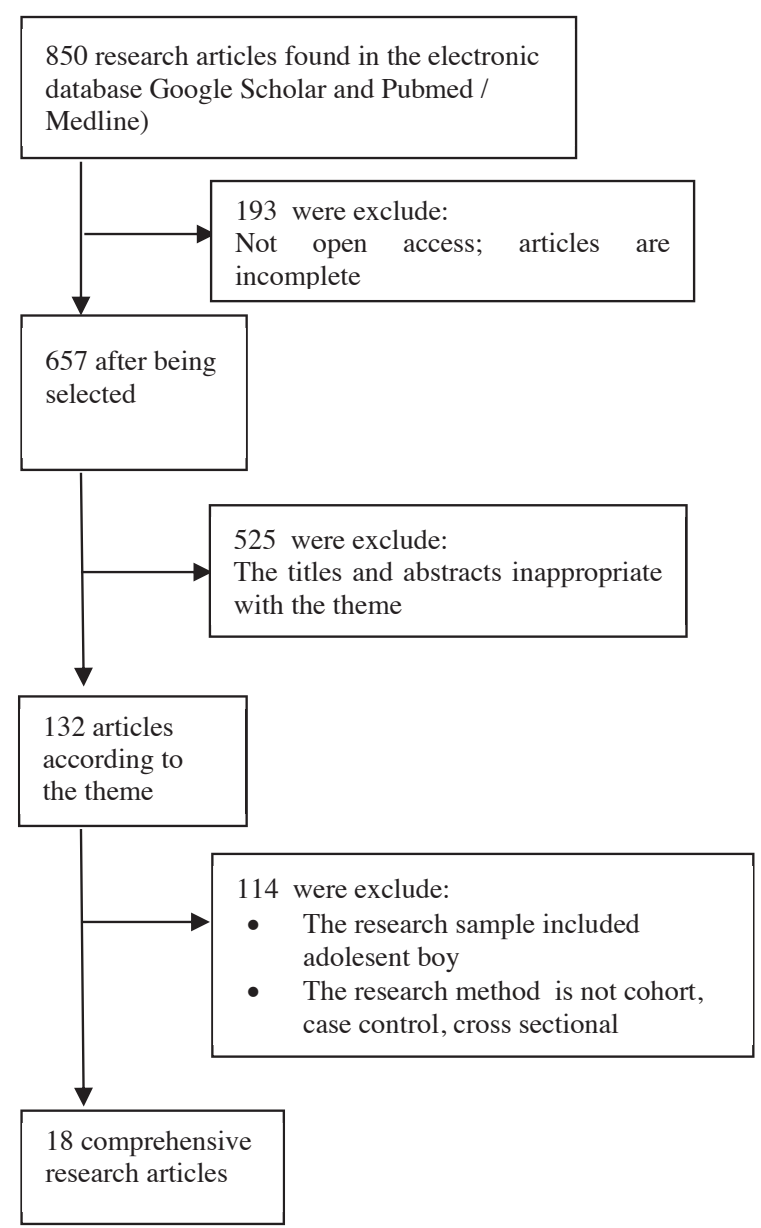

Figure 1. Flow diagram of research articles on the effect of body image on nutritional status in adolescent girls

to select the research articles were the results that showed the correlation, effect, or risk factors of body image on nutritional status, and research samples on adolescent girls. Research articles were excluded if the research method was literature review, systematic review, meta-analysis, the research sample was adolescent girl and boy, and the results of the research showed no correlation, effect, or risk factors of from body image on the nutritional status of adolescent girls. Figure 1 shows the process of research article selection.

\section{RESULTS AND DISCUSSION}

There are some factors related with body image and it correlation with nutritional status. Seven study shows that body image can directly affect with nutritional status (Table 1). Body image can not affect alone on nutritional status, together with food intake and physical activity factors affect 
nutritional status in female adolescent (Table 2). Table 3. shows that knowledge, peers and body image have correlation with nutritional status in female adolescent.

\section{Body Image and Nutritional Status}

Table. 1 results of literature review on body image and nutrition status association. The

Table 1. Results of Literature Review on Body Image and Nutrition Status Association

\begin{tabular}{|c|c|c|}
\hline Research Title and Author & Research Methods & Result \\
\hline $\begin{array}{l}\text { Correlation of body image } \\
\text { and nutritional status } \\
\text { of female students at } \\
\text { SMA Negeri } 9 \text { Surabaya } \\
\text { (Bimantara, Adriani and } \\
\text { Suminar, 2019) }\end{array}$ & $\begin{array}{l}\text { Design: Observational, cross-sectional } \\
\text { Subjects: } 76 \text { students of class XI and XII } \\
\text { Data collection: BSQ-34 questionnaire and } \\
\text { anthropometric measurements include weight } \\
\text { and height } \\
\text { Data analysis: spearman test }\end{array}$ & $\begin{array}{l}83 \% \text { of respondents have adequate nutrition } \\
\text { knowledge, } 74 \% \text { have a positive body image, and } \\
71 \% \text { have a normal nutritional status. Based on the } \\
\text { Spearman correlation test, it was found that there } \\
\text { was a significant correlation between body image } \\
\text { and nutritional status }(\mathrm{p}=<0.001 ; \mathrm{r}=0.533)\end{array}$ \\
\hline $\begin{array}{l}\text { Does Nnutritional Status } \\
\text { Interfere with adolescents' } \\
\text { body image perception? } \\
\text { (Menconça, Karla L, et al. } \\
\text { 2014) }\end{array}$ & $\begin{array}{l}\text { Design : Dexcriptive cross-sectional } \\
\text { Subjects : Female Adolescent }(12-18 \text { y.o }) \\
\text { who are scholar } \\
\text { Data Collection: antropometric, BI was } \\
\text { evaluated by Application Scale which } \\
\text { proposed by Childress, Brewerton, Hodges \& } \\
\text { Jarrel at } 1993 \text {. } \\
\text { Data Analysis : Pearson's Chi-square and } \\
\text { Fisher's exact test }\end{array}$ & $\begin{array}{l}\text { Underweight teenagers did not regard themselves } \\
\text { thin }(35 \%) \text {. Otherwise, } 39.1 \% \text { of the overweight } \\
\text { individuals and } 62.1 \% \text { of the obese did not see } \\
\text { themsleves in their classification, other words, they } \\
\text { satisfied what they are to be. Meanwhile, there were } \\
29.8 \% \text { normal BMI students who were dissatisfied } \\
\text { and want to lose gain. }\end{array}$ \\
\hline $\begin{array}{l}\text { Perceptions of body size } \\
\text { with the nutritional status } \\
\text { of adolescent girls in } \\
\text { Palangkaraya (Aprilianti, } \\
\text { 2013). }\end{array}$ & $\begin{array}{l}\text { Design: Observational, cross-sectional } \\
\text { Subjects: } 134 \text { female students ( } 3 \text { SMA / SMK } \\
\text { taken by proportional random sampling), 16- } \\
18 \text { group age } \\
\text { Collecting data: Using the Body Shape } \\
\text { Questionnaire (BSQ) and antropometric } \\
\text { measurements. } \\
\text { Data analysis: Kappa analysis }\end{array}$ & $\begin{array}{l}59.7 \% \text { of respondents were dissatisfied with body } \\
\text { size. } 29.8 \% \text { felt overweight, and } 51.4 \% \text { had a } \\
\text { normal BMI. Based on the analysis, the perception } \\
\text { of body size affects the nutritional status of } \\
\text { adolescents. Besides, eating behavior and economic } \\
\text { conditions are also related to nutritional status. }\end{array}$ \\
\hline
\end{tabular}

Correlation of body mass Design: Observational, cross-sectional index and body image for Subjects: 56 students of class XII

students of SMK Sentra Collecting data: Using the Body Shape Medika in 2018 (Batubara Questionnaire (BSQ), measuring weight and dan Batubara, 2019) height Data analysis: chi-square test
There were $6.2 \%$ thin students (by BMI) who had negative body image. Then, $57.1 \%$ normal student (by BMI) who had negative body image. While, students who had overweight status by BMI, they satisfied with their body (10.5\%). According to chi-square analysis, there were significant correlation between body image and nutritional status $(\mathrm{p}<0.001)$

Body image satisfaction in Design: Observational, cross-sectional student from the sixth grade Subjects: 1230 adolescent girl with a group of public school in Caxias do aged 11-14

There were $71.5 \%$ of adolescent girls who were dissatisfied with their body shape. There was a significant correlation between body image and Sul, southern Brazil (Finato Data collecting: using the Body Shape nutritional status (PR = 3.84, 95\% CL 2.72-5.41). et al., 2013) Questionnaire (BSQ-34), measuring body weight, height, and waist circumference. Data analysis: chi-square test

A Study on Consciousness Design: Observational, cross-sectional

Among $73.4 \%$ satisfied girls, there were $32.8 \%$ of Adolescent Girls About Subjects: 585 adolescent girls of age 10-19 Their Body Image (Dixit et years al., 2011)

underweight girl and $38.4 \%$ stunted girl. The difference between actual body weight and perceived body image was used to identifying the $\begin{array}{ll}\text { questionnaire which were include estimation about health. girls of high and medium } \\ \text { some questions about perceived image; BMI with thin and normal perceived body image } \\ \text { anthropometric measurement } & \text { were categorized into underestimation, and girls of }\end{array}$ $\begin{array}{ll}\text { questionnaire which were include estimation about health. girls of high and medium } \\ \text { some questions about perceived image; BMI with thin and normal perceived body image } \\ \text { anthropometric measurement } & \text { were categorized into underestimation, and girls of }\end{array}$ $\begin{array}{ll}\text { questionnaire which were include estimation about health. girls of high and medium } \\ \text { some questions about perceived image; BMI with thin and normal perceived body image } \\ \text { anthropometric measurement } & \text { were categorized into underestimation, and girls of }\end{array}$ Data analysis: descriptive analysis and chi- low and median BMI with perceived body image square test of fatty were categorized into overestimation. This study found $32.8 \%$ of girls had overestimated their weight, while only $4.9 \%$ of girls had underestimated their weight

Perception of body image of Design: Observational cross-sectional adolescent and their parents Subjects: 914 adolescent girls with the age in relation to the nutritional group of 10-19 and their parents Body image had a significant correlation with BMI ( $p<0.001)$, body weight $(p<0.001)$, abdominal circumference $(\mathrm{p}<0.001)$, systolic blood pressure status and blood pressure Data collecting: questionnaires, weight, height, (Vieira et al., 2015)

\section{waist circumference} and blood pressure
Data analysis: Chi-square test and Spearman parents $(\mathrm{p}<0.001)$.

$(p<0.001)$ and diastolic blood pressure $(p=0.013)$.

Then there was also a significant correlation of children's nutritional status and body image of their correlation test 
result of research have been accomplished by Aprilianti (2013) showed if an individual with a negative body image does not always have a poor nutritional status, on the other hand, an individual with a positive body image doubtful have a normal nutritional status. This occurs because nutritional status is not only influenced by perceptions but is also influenced by many factors including socio-economic conditions in the family, socioculture, peers, media, family, and the environment. (Aprilianti, 2013).

Research of Aprilianti (2013) is also reinforced by research which states that nutritional status is not only influenced by body image but also influenced by nutritional intake and individual infectious diseases. (Cahyaningrum, 2013). Other studies suggest that a negative body image can increase when an individual thinks that their body shape is inappropriate with their desire. (Batubara and Batubara, 2019).

Study by Batubara and Batubara (2019) explained that female students, who had a normal BMI with negative body image, were due to a lack of self-confidence and felt that they were bigger than their peers who were thinner according to their own version. Therefore, they tend to go on a diet to lose weight. Meanwhile, female students, who had overweight and a positive body image, they had higher self-confidence. So, they tend not to care and will continue their unhealthy habit.

The appearance of a body image to nutritional status is triggered by the mass media presenting by public figures who have a perfect appraisal from the public. An individual who has an idol will admire all the behavior and habits of their idol. It can trigger to a negative body image. Negative body image also affects the nutritional status, because negative body image makes an individual less satisfied with their body shape. Subsequently, it can change their dietary behavior (Putri, Ani and Ariastuti, 2018).

Researched by Mendonça et al., (2014), body image could affects nutritional status. The results of it showed that dissatisfaction with body shape can affect lossing and gaining in body weight. The incidence of body image can be influenced by the media and the general public. The standard of community assessment is very influential on a person's body image. Person who has a normal weight may still losing some weight because of standards in society, besides, it is different with the exact nutritional status standards.

While the research by Vieira et al., (2015) showed that there was a significant correlation between adolescent nutritional status with the body image of parents. Parents who have a negative body image will give an inappropriate diet to their children. Children who according to their parents are fat, but by BMI they are thin, will be forced to lose weight. Likewise, children who according to their parents are thin, but by BMI are fat, will be given food more than their requirement.

There is significant relationship between body image and nutritional status (Dixit et al., 2011). In that study showed body image in femal adolescents was caused by the surrounding environment. The body image in female adolescent in rural, urban and slum environment has different results. Most of satisfied girls was in slum area who had underweight and stunted of nutritional status. These environmental factors lead to different adolescent body images. Lack of understanding of body image is one of factors can make this differences. Thus, an inaccurate understanding will causing in nutritional status and eating disorders in female adolescents.

\section{Food Intake, Physical Activity, and Body Image on Nutritional Status}

Articles in Table. 2 show several studies related to food intake, physical activity, and body image, all of which are related to nutritional status in adolescents. This happens because eating pattern and activities of adolescents will change follow the adolescent's desire to have slim and tall body shape. Research by Yusintha et al., (2018) showed that there was a correlation between eating behavior and nutritional status of adolescent girls. Adolescents can choose food without attention to nutrition. Besides, diet changes because adolescents make an effort to get an ideal body.

The changes in meal patterns are also supported by additional activities at school such as extracurricular activities both inside and outside school, that makes female students skip their meals. Students choose fast food to shorten the time and most of them often missed their breakfast. Skipping breakfast for students is considered one of the first 
Table 2. Food intake, physical activity, and body image on nutritional status

\begin{tabular}{|c|c|c|}
\hline Research Title and Author & Research Methods & Result \\
\hline $\begin{array}{l}\text { The correlation of eating } \\
\text { behavior and body image } \\
\text { with the nutritional status of } \\
\text { adolescent girls with the age } \\
\text { group of 15-18 (Yusintha and } \\
\text { Adriyanto, 2018) }\end{array}$ & $\begin{array}{l}\text { Design: Observational, cross-sectional } \\
\text { Subjects: } 93 \text { female students aged } 15-18 \text { years } \\
\text { Data collecting: BSQ-34, measurement of weight } \\
\text { and height } \\
\text { Data analysis: correlation test with Spearman } \\
\text { test }\end{array}$ & $\begin{array}{l}\text { There were } 57 \% \text { have good eating behavior, } \\
80.6 \% \text { have positive body image and } 72 \% \text { have } \\
\text { normal nutritional status. The results of the } \\
\text { Spearman correlation test showed that there } \\
\text { was a correlation between eating behavior and } \\
\text { the nutritional status of adolescent girls (result } \\
\mathrm{p}=0.013 \mathrm{r}=0.256 \text { ). In addition, the Pearson } \\
\text { correlation test results also showed correlation } \\
\text { of the body image and nutritional status ( } \mathrm{p}= \\
0.002 ; \mathrm{r}=0.315 \text { ). }\end{array}$ \\
\hline
\end{tabular}

Perception of the body image Design: Observational, cross-sectional There were female adolescent who had less is related to the nutritional Subjects: 95 female students of class X, XI, and energy intake (6.3\%), less protein intake (3.1\%), status of SMA N 1 Gianyar XII with the age group of 16-18 were selected by less fat intake (3.1\%) and less carbohydrates students (Putri, Ani, and random sampling technique intake (3.1\%) but have a negative body image. Ariastuti, 2018) Data collecting: anthropometry, semiquantitative In addition, there is a significant relationship food frequency question (SQ-FFQ), Body Shape between perceptions of body image and Questionnaire (BSQ-34). $\quad$ nutritional status $(\mathrm{p}<0.05)$.

Data analysis: chi-square test

The correlation of the Design: Observational, cross-sectional application of balanced Subjects: 121 female students aged 15-18 years nutritional status, adequate carbohydrate intake nutrition guidelines and Data collecting: interviews with the food (90.1\%), adequate fat intake (54.5\%), adequate body image with nutritional recall questionnaire, PAL, and the Body Shape protein intake $(67.8 \%)$, light physical activity status at SMK Nusantara 2 Questionnaire (BSQ-34) Kesehatan 2016 (Permatasari Data analysis: Chi-Square and Setiawati, 2017)

(79\%), the habit of do not have breakfast every day $(52.9 \%)$ and negative body image (66.9\%). Bivariate test result showed that there were correlation between body image $(\mathrm{p}<0.05$; $\mathrm{OR}=3.333$ ), protein intake ( $<<0.05$; OR: 3.632), fat intake $(\mathrm{p}<0.05 ; \mathrm{OR}=12.000)$ and physical activity $(\mathrm{p}<0,05$; OR 6.146$)$ with nutritonal status in female students

Correlation of physical Design: Observational, cross-sectional There was a significant correlation of body activity and body image Subjects: 262 students of class X, XI, and XII image and nutritional status of students ( $p=$ with nutritional status of with purposive sampling technique $\quad 0.000)(p<0.05)$ but there was no correlation high school students SMA Data collecting: physical activity and body image of physical activity and nutritional status $(\mathrm{p}=$ Yayasan Pupuk Kaltim perception with the help of a questionnaire, 0.000) ( $p>0.05)$.

Bontang (Prisilia, Rachmi, measurement of BMI (weight and height)

and Aminyoto, 2019) Data analysis: the Kolmogrov-Smirnov test

\begin{tabular}{|c|c|c|}
\hline $\begin{array}{l}\text { Affect of body image and } \\
\text { eating habits with nutritional } \\
\text { status at SMAN } 1 \text { KAMPAR } \\
\text { in } 2017 \text { (Hendarini, 2018) }\end{array}$ & $\begin{array}{l}\text { Design: Observational, cross-sectional } \\
\text { Subjects: } 229 \text { female students } \\
\text { Data collecting: Body Shape Questionnaire (BSQ), } \\
\text { questionnaire on eating habits and anthropometric } \\
\text { measurements of body weight and height } \\
\text { Data analysis: chi-square test }\end{array}$ & $\begin{array}{l}\text { The results showed that most of the respondents } \\
\text { had poor eating habits }(53.3 \%) \text { and negative } \\
\text { body image }(51.5 \%) \text {. Based on the results test } \\
\text { statistically, there was a significant correlation } \\
\text { of eating habits }(\mathrm{p}=0.029) \text {, body image ( } \mathrm{p} \\
=0.039) \text {, and the nutritional status of the } \\
\text { students. }\end{array}$ \\
\hline
\end{tabular}

The correlation of body Design: Observational, cross-sectional image and physical activity Subjects: 78 female students positive body image were 25.6\%. Respondents Respondents with normal nutritional status and with the status of VII grade Data collecting: assistance (BSQ) and PAL and with nutritional status of $9 \%$ fat and $12.8 \%$ female students at SMPN 20 anthropometric measurements Surabaya (Nur, Mawarda and Data analysis: Spearman's Rank Correlation test Amin, 2019) with obesity nutritional status accompanied by moderate negative body image. Based on the analysis, there was a significant correlation between body image and nutritional status but not with physical activity. 


\begin{tabular}{|c|c|c|}
\hline Research Title and Author & Research Methods & Result \\
\hline $\begin{array}{l}\text { The correlation of body } \\
\text { image and eating behavior } \\
\text { with the nutritional status } \\
\text { of adolescent girls at SMA } \\
\text { Theresia School Semarang } \\
\text { (Widianti and Candra, 2012) }\end{array}$ & $\begin{array}{l}\text { Design: Observational, cross-sectional } \\
\text { Subjects: } 72 \text { students of class X, XI, and XII with } \\
\text { the age group of 16-18 } \\
\text { Data collecting: The Body Shape Questionnaire } \\
\text { (BSQ-34) questionnaire was done by FGD, and } \\
\text { anthropometric measurements were carried out } \\
\text { including body weight and height. } \\
\text { Data analysis: Kolmogorov Smirnov test and } \\
\text { Pearson correlation test }\end{array}$ & $\begin{array}{l}40.3 \% \text { of respondents were not satisfied with } \\
\text { their body shape. Most of the } 56.9 \% \text { of subjects } \\
\text { had not carried out good eating behavior. Based } \\
\text { on bivariate analysis, there was a significant } \\
\text { correlation of body image and nutritional status } \\
(\mathrm{r}=0.482 \mathrm{p}=0.001) \text { and eating behavior with } \\
\text { nutritional status }(\mathrm{r}=0.507 \mathrm{p}=0.001) .\end{array}$ \\
\hline $\begin{array}{l}\text { The correlation of the body } \\
\text { image, physical activity, } \\
\text { and knowledge of balanced } \\
\text { nutrition with the incidence } \\
\text { of obesity in overweight girls } \\
\text { in SMA Negeri } 9 \text { Semarang } \\
\text { (Intantiyana, Widajanti, and } \\
\text { Zen, 2018) }\end{array}$ & $\begin{array}{l}\text { Design: Observational cross-sectional } \\
\text { Subjects: } 67 \text { adolescent girls with a total sampling } \\
\text { technique } \\
\text { Data collecting: structured questionnaire } \\
\text { interviews, recall, physical activity, measurement } \\
\text { of body weight and height } \\
\text { Data analysis: chi-square test }\end{array}$ & $\begin{array}{l}\text { Based on the results of the chi-square test, } \\
\text { there was a correlation between body image } \\
(\mathrm{p}=0.008) \text { and physical activity }(\mathrm{p}<0.001) \\
\text { with nutritional status. However, there was } \\
\text { no correlation between balanced nutrition } \\
\text { knowledge }(\mathrm{p}=0.837) \text { and over nutritional } \\
\text { status. }\end{array}$ \\
\hline
\end{tabular}

steps to lose weight, but this is not appropriate because it could reduce the concentration. Also, it could cause obesity because when the break time comes, students tend to binge eating or eat more than their normal habit (Widianti et al, 2012).

This is consistent with the research of Hendarini (2018) which showed that there is was correlation between eating habits and nutritional status. The results of the research indicated that most respondents with over nutritional status are consuming more macronutrients (carbohydrates, fats, and proteins) and also tended to have the habit of eating other foods outside of mealtime. Adolescents often consume high calories and fat snacks but low nutrients (Widianti et al, 2012). The negative perception of body image will encourage female adolescent to take various actions to achieve their goal body shape. However, these actions are harmful oftenly to health and affect their nutritional status, such as decrease food intake dramatically drastic reductions in food intake (Merinta, Veni and Djunaedi, 2012; Valter et al., 2014; Putri, Ani and Ariastuti, 2018).

Besides influenced by food intake, nutritional status is also influenced by physical activity. WHO (2010) recommended the physical activity for adolescents was physical activities with moderate level to severe with a minimum of 60 minutes/ day. Based on recommendations by Indonesian Ministry of Health ((Kemenkes RI, 2018) in the Germas program that physical activity is carried out at least 30 minutes each day.
Physical activity for teenagers is not only beneficial for maintaining physical health or other body organs, but also mental health. Study by Prisilia, Rachmi and Aminyoto, (2019), explained that by doing physical activity, self-esteem in adolescents will increase. This self-esteem is important for psychological well-being, building a positive body image, increasing self-efficacy, and preventing the teenager from experiencing depression, anxiety, and high-risk behaviors such as consume/ abuse the drugs (example: weight loss drugs which are harmful to adolescent's health).

\section{Nutrition Knowledge, Peer Roles and Body Image on Nutritional Status}

Table. 3 consists of articles related to nutritional knowledge, role of peers, body image, and its relation to nutritional status. Body image is triggered by several factors such as age, gender, nutrition knowledge, social media, and the environment (Denich et al., 2015).

Research by (Syati et al., 2019) showed that body image increase because of peer influence. Peers are used to making comments about their friends' physical appearance. It leads to the emergence of a body image, either negative or positive. However, peers are not the only factor that triggers body image, thus it affects nutritional behavior which leads to Parents have a crucial contribution as an environmental factor to define the adolescent nutritional status. Even adolescents are independent to pick their meal, parents still 
Table 3. Knowledge, peers, and body image on nutritional status

\begin{tabular}{|c|c|c|}
\hline Research Title and Author & Research Methods & Result \\
\hline $\begin{array}{l}\text { Correlation of peers and body } \\
\text { image on nutritional status of } \\
\text { women of childbearing age before } \\
\text { marriage in MAN } 1 \text { Lampung } \\
\text { Tengah, Kecamatan Terbanggi } \\
\text { Besa, Kabupaten Lampung Tengah } \\
\text { (Syati et al., 2019) }\end{array}$ & $\begin{array}{l}\text { Design: Observational, cross- } \\
\text { sectional } \\
\text { Subjects: } 115 \text { adolescent girls } \\
\text { Data collecting: Body Shape } \\
\text { Questionnaire (BSQ-34) for body } \\
\text { image variables peer influence scale } \\
\text { for peer variables and anthropometric } \\
\text { measurements. Data analysis: chi- } \\
\text { square test and Fisher exact }\end{array}$ & $\begin{array}{l}\text { There were } 64.3 \% \text { normal nutritional status, } 22.6 \% \\
\text { over nutritional status, and } 13.1 \% \text { under nutritional } \\
\text { status. In the body image variable, } 73.9 \% \text { were satisfied } \\
\text { and } 26.1 \% \text { were dissatisfied. In the peer variable, it } \\
\text { was found that } 89.4 \% \text { had no effect and } 10.4 \% \text { had } \\
\text { the effect. Based on the bivariate analysis, the results } \\
\text { showed that there was a correlation between body } \\
\text { image and nutritional status }(\mathrm{p}=0.001) \text { but there was } \\
\text { no correlation with peers }(\mathrm{p}=0.517) \text {. }\end{array}$ \\
\hline $\begin{array}{l}\text { The correlation of nutritional } \\
\text { knowledge, body image, and eating } \\
\text { behavior with the nutritional status } \\
\text { of students at SMAN } 6 \text { Jambi in } \\
2015 \text { (Irmayanti, 2015) }\end{array}$ & $\begin{array}{l}\text { Design: Observational, cross- } \\
\text { sectional } \\
\text { Subjects: } 72 \text { students taking the } \\
\text { proportional technique } \\
\text { Data collecting: using a questionnaire } \\
\text { and measuring nutritional status } \\
\text { (weight and height) } \\
\text { Data analysis: Chi-Square test }\end{array}$ & $\begin{array}{l}\text { The results showed that } 56.9 \% \text { of students had good } \\
\text { knowledge of nutrition, } 54.2 \% \text { had negative body } \\
\text { image, } 54.2 \% \text { had good eating habits, and } 51.4 \% \\
\text { had normal nutritional status. While the bivariate test } \\
\text { results showed that there was a significant correlation } \\
\text { of nutritional knowledge }(\mathrm{p}=0.01) \text {, body image ( } \\
=0.03) \text {, eating behavior }(\mathrm{p}=0.00) \text { and nutritional } \\
\text { status. }\end{array}$ \\
\hline $\begin{array}{l}\text { The correlation of self-esteem and } \\
\text { body image in early adolescents } \\
\text { who are obese (Nurvita, 2015) }\end{array}$ & $\begin{array}{l}\text { Design: Observational, cross- } \\
\text { sectional } \\
\text { Subjects: } 41 \text { adolescent girls with } \\
\text { the age group of } 12-15 \\
\text { Data collecting: using a self- } \\
\text { esteem questionnaire and a BSQ-34 } \\
\text { questionnaire } \\
\text { Data analysis: Spearman correlation } \\
\text { test }\end{array}$ & $\begin{array}{l}\text { The results showed that most of the respondents had } \\
\text { fewer eating habits }(53.3 \%) \text { and negative body image } \\
(51.5 \%) \text {. Based on the chi-square test, there was a } \\
\text { significant correlation between eating habits ( } \mathrm{p}= \\
0.029) \text {, body image }(\mathrm{p}=0.039) \text {, and the nutritional } \\
\text { status of students. }\end{array}$ \\
\hline
\end{tabular}

take the role to provide the meal at home and create a childhood meal pattern. Research of Febriani (2019) showed that parents also contribute to the adolescent's nutritional status, both over or under nutrition. The parent's contribution that affects adolescent nutritional status provides the amount of allowance and food available at home. The allowance given will affect the consumption behavior of adolescent girls outside the home. Additionally, adolescents tend to spend their allowance for food thus it can increase their nutritional status to be over. Research by Nusa et al (2013) showed that most adolescents spend $1 / 3$ of the allowance for fast food which has high fat and carbohydrates.

The adolescent girls' knowledge regarding nutrition and health affects several things, such as nutritional behavior related to food consumption, physical activity, and perceptions of body shape. Research of Intantiyana et al, (2018) explains that the insufficient of adolescent nutritional knowledge is consistent with their inappropriate diet, they make meal restrictions without knowing their need. This changes the food choice and makes inappropriate nutritional needs. Meanwhile, research by Florence (2017) indicates that a lack of nutrition knowledge is associated with abnormal nutritional status (under or over). This correlation happens because it is related to a uncorrect of choosing type and quantity of food (Sediaoetama, 2000).

Most of the nutritional problems (under and over nutrition) in adolescents emerge from negative body image, this is due to dissatisfaction with their body. According to research by Nurvita (2015) which showed that there was a significant correlation between self-esteem and body image in young adolescents who had obese nutritional status. The lower of self-esteem, the lower the body image. This happens because there are changes both physically and mentally in young adolescents, thus adolescents are quite difficult to accept these changes. Additionally, self-esteem is also influenced by pressure as a peer's body image standard.

This literature review contains some limitations. That is, adolescents measured are only girl, not including boys thus it can't be generalized. 
This is because researchers want to focus on adolescent girls as part of the First 1000 Days of Life program whose nutritional status should be considered.

\section{CONCLUSION}

Several factors affect the nutritional status of adolescent girls, one of which is body image. Body image is a self-perception of an individual body shape. Body image is related to nutritional status of adolescent girls, whether under or over nutrition. This is related to nutritional behavior which involves knowledge of nutrition and meal pattern of an adolescent girl. Furthermore, there is also a correlation of physical activity that is not balanced with food intake and environmental contribution, such as family and peers, which also affects nutritional behavior and body image.

\section{REFERENCE}

Aprilianti, C. (2013). Persepsi Terhadap Ukuran Tubuh Dengan Status Gizi Remaja Putri Di Kota Palangka Raya. Jurnal info kesehatan 52(2), pp. 285-299.

Bapenas RI (2012). Kerangka Kebijakan: Gerakan Sadar Gizi Dalam Rangka Seribu Hari Pertama Kehidupan (1000 HPK). Jakarta: Lembaga Perencanaan dan Pembangunan Nasional.

Batubara, S. dan Batubara, W. A. (2019). Hubungan Indeks Massa Tubuh Dengan Body image pada Siswi SMK Sentra Medika Tahun 2018. Jurnal kajian kesehatan masyarakat.pp. 14-21.

Bimantara, M. D., Adriani, M. dan Suminar, D. R. (2019). Hubungan Citra Tubuh dengan Status Gizi pada Siswi di SMA Negeri 9 Surabaya. Amerta Nutrition, 3(2), pp. 85-88.

Brown, J. (2011) Nutrition Through The Life Cycle. 2nd edn. Belmont: Wadsworth.

Cahyaningrum, H. D. (2013). Hubungan Antara Body image dengan Status Gizi Pada Remaja Putri Kelas XI Ips Di SMA Batik 1. Skripsi. Universitas Muhammadiyah Surakarta.

Denich, A. U. dan Ifdil, I. (2015). Konsep Body image Remaja Putri. Jurnal Konseling dan Pendidikan, 3(2), pp. 55-61.

Destiara, F., Hariyanto, T. dan Ragil, C. A. (2016). Hubungan Indeks Massa Tubuh (IMT) dengan Body image pada Remaja di Asrama Putri Sangau Malang', Journal Nursing News, XI(1), pp. 31-37.
Dixit, S. et al. (2011) 'A study on consciousness of adolescent girls about their body image', Indian Journal of Community Medicine, 36(3), pp. 197-202. doi: 10.4103/0970-0218.86520.

Febriani, R. T. (2019). Body image dan Peran Keluarga Remaja Status Gizi Lebih di Kota Malang. Jurnal Informasi Kesehatan Indonesia, 5(2), pp. 72-78.

Finato, S. et al. (2013). Body image insatisfaction in students from the sixth grade of public schools in Caxias do Sul, Southern Brazil. rev paul pediatr31(1), pp. 65-70.

Florence, A. G. (2017) Hubungan Pengetahuan Gizi dan Pola Konsumsi Dengan Status Gizi Pada Mahasiswa TPb Sekolah Bisnis dan Manajemen Institut Tekonologi Bandung. Skripsi. Universitas Pasundan.

Hendarini, A. T. (2018). Pengaruh Body image dan Kebiasaan Makan dengan Status Gizi di SMAN 1 Kampar tahun 2017. Jurnal Gizi (Nutritions Journal ), 2(2), pp. 138-145.

Intantiyana, M., Widajanti, L. dan Zen, M. R. (2018). Hubungan Citra Tubuh, Aktivitas Fisik Dan Pengetahuan Gizi Seimbang Dengan Kejadian Obesitas Pada Remaja Putri Gizi Lebih di SMA Negeri 9 Kota Semarang. e-journal Kesehatan Masyarakat, 6, pp. 404-412.

Irmayanti.(2015). Hubungan Pengetahuan Gizi , Body image dan Perilaku Makan dengan Status Gizi Siswi Sman 6 Kota Jambi Tahun 2015. Scientia journal, 4(3), pp. 198-203.

Jannah, I. N. dan Muniroh, L. (2019). Body image, Tingkat Kecukupan Zat Gizi, dan Fad Diets Pada Model Remaja Putri Di Surabaya. Media Gizi Indonesia, 14(1), pp. 95-105.

Kemenkes RI. (2018). Rajin Aktivitas Fisik. Jakarta: Promkes.

Kemenkes RI. (2019). Laporan Nasional Riskesdas Tahun 2018. Jakarta : Lembaga Penerbit Badan Penelitian dan Pengembangan

Mawaddah, N. dan Muniroh, L. (2019). Hubungan Body image dan Tingkat Kecukupan Zat Gizi Makro dengan Status Gizi Pada Remaja Putri SMA Negeri 3 Surabaya, Jurnal Keperawatan Muhammadiyah, pp. 208-215.

Mendonça, K. L. et al. (2014) 'Does nutritional status interfere with adolescents' body image perception?', Eating Behaviors, 15(3), pp. 509-512. doi: 10.1016/j.eatbeh.2014.06.011.

Muliyati, H., Ahmil dan Mandola, L. (2019). Hubungan Citra Tubuh, Aktivitas Fisik, dan Pengetahuan Gizi Seimbang Dengan Status 
Gizi Remaja Putri. CHMK Midwifery Scientitifi, 2(1), pp.-22-32.

Normate, E. S., Nur, M. L. dan Toy, S. M. (2017). Hubungan Teman Sebaya, Citra Tubuh dan Pola Konsumsi dengan Status Gizi Remaja Putri. Unnes Journal of Public Health, 6(3), pp.51-57

Nur, A. O., Mawarda, N. H. dan Amin, N. (2019). Hubungan Body image dan Aktivitas Fisik dengan Status Gizi Remaja Putri Kelas VIII SMPN 20 Surabaya. Sport and Nutrition Journal, 1(1), pp. 27-32.

Nurvita, V. (2015). Hubungan Antara Self-esteem dengan Body image pada Remaja Awal yang Mengalami Obesitas. Jurnal Psikologi Klinis dan Kesehatan Mental, 4(1), pp. 1-9.

Nusa, A. F. A. dan Adi, A. C. (2013). Hubungan faktor perilaku, frekuensi konsumsi fast food, diet dan genetik dengan tingkat kelebihan berat badan. Media Gizi Indonesia, 9(1), pp. 20-27. Pasaribu, V. S., Rahmayati, E. dan Puri, A. (2015). Hubungan perubahan fisik usia remaja dengan rasa percaya diri pada siswi kelas 7.Jurnal Keperawatan, XI(1), pp. 81-85.

Permatasari, P. dan Setiawati (2017). Hubungan Penerapan Pedoman Gizi Seimbang dan Citra Tubuh dengan Status Gizi di SMK Nusatara 02 Kesehatan Tahun 2016. jurnal ilmu kesehatan, 1(1), pp. 70-78.

Prisilia, C., Rachmi, E. dan Aminyoto, M. (2019). Hubungan Aktivitas Fisik dan Body image dengan Status Gizi Siswi Sma Yayasan Pupuk Kaltim. jurnal kebidanan mutiara mahakam, 7(2), pp. 99-112.
Putri, N. M. D. P., Ani, L. S. dan Ariastuti, L. P. (2018). Persepsi Body image Berhubungan dengan Status Gizi Pada Pelajar SMA Negeri 1 Gianyar. E-Jurnal Medika, 7(11), pp. 1-5.

Sediaoetama, A. D. 2000. Ilmu Gizi Untuk Mahasiswa dan Profesi Jilid I. Jakarta : Dian Rakyat. Jakarta.

Syati, S. N. et al. (2019). Hubungan Teman Sebaya dan Citra Tubuh Terhadap Status Gizi Wanita Usia Subur Pranikah di MAN 1 Lampung Tengah. Medula 8(1), pp. 1-6.

Vieira, R. S. et al. (2015). Perception of body image of adolescents and of their parents in relation to the nutritional status and blood pressure. Nutr Hop,31(4), pp. 1839-1844.

WHO. (2010). Physical Activity In Guide to Community Preventive Service.

Wati, D. K. dan Sumarmi, S. (2017). Citra Tubuh Pada Remaja Perempuan Gemuk Dan Tidak Gemuk. Amerta Nutr, pp. 398-405.

Widianti, N. U. R. (2012). Hubungan Antara Body image Dan Perilaku Makan Dengan Status Gizi Remaja Putri. Skripsi. Universitas Diponegoro.

Widianti, N. dan Candra, A. K. (2012). Hubungan antara Body image Dan Perilaku Makan Dengan Status Gizi Remaja Putri di SMA Theresiana Semarang, Journal of Nutrition College, 1(1), pp. 384-404.

Yusintha, A. N. dan Adriyanto (2018) . Hubungan Antara Perilaku Makan dan Citra Tubuh dengan Status Gizi Remaja Putri Usia 15-18 Tahun . Amerta Nutr, pp.147-154, 